\title{
THE CORRELATION BETWEEN STUDENTS' ANXIETY AND SPEAKING PERFORMANCE AT THE SECOND GRADE IN SMAN 1 PANTAI CERMIN KABUPATEN SOLOK
}

\author{
Peni Oktavia ${ }^{1}$, Syahrul ${ }^{*}$ \\ State Islamic Collage of Bukittinggi, Bukittinggi ${ }^{1,2}$ \\ syahrulsabri@gmail.com
}

\begin{abstract}
The background of this research was the presence of anxiety among some students in their English-speaking activities in the school. In addition, some students had anxieties when speaking English because anxiety affected performance while some other students had no problems. This research used a quantitative approach in the type of correlation design. The population of this research was all class of the second grade in SMAN 1 Pantai Cermin and all of them became sample because they were less than a hundred. The data was got through a questionnaire and documentation. The students fill the questionnaires directly relate to their anxiety in speaking. The data of the documentation were taken from the students' final scores in the speaking. To analyze the data, the researcher used the SPSS version 20 for windows. In analyzing the data, the researcher used the Person Product Moment formula to find out the significant correlation, to find out the correlation direction and to find out the correlation magnitude. The results of the research showed that there was a correlation between students' anxiety and speaking performance at the second grade of SMAN 1 Pantai Cermin.
\end{abstract}

Keywords: English Language Learning, Speaking performance, Students' Anxiety.

\section{INTRODUCTION}

In the Globalization era, English is one of the languages that should be learned by students, especially at Senior High School. Besides, as an international language, English is very important and has many interrelationships with various aspect of life own by a human being (Iksan \& Duriani, 2015). In Learning English, four skills should be mastered by the students such as listening, speaking, reading, and writing. Speaking is one of the skills that have an important role in the language learning process. speaking is one of the most important skills of the four language skills because individuals who learn a language are referred to as the speakers of that language (Penny Ur,1991). In addition, speaking can help students to use and effectively transmit knowledge. Indeed, it is an important skill that should be mastered by the students and should be applied in daily communication.

Speaking is a way for the students to express their knowledge, to share their feelings and to show their performance. The students can make social contact with others when 
interacting. They can express their thoughts, even they can respond directly to what the people say to them, so the students become to understand what they say. In addition, there are three main functions of speaking that is talk as interaction, talk as a transaction, and talk as performance (Richards, 2008). In conclusion, those function of speaking will help the students to understand what is said.

Generally, speaking performance can be defined as the act of express ideas orally. Related to the definition of speaking performance, speaking performance is public talk that talks to transmit previous information to an audience, such as classroom presentation, public announcement, and speeches (Jack Richards, 2008). Some students when communicating with other people may feel hesitant to speak in English, while others who have their encouragement will be brave to practice speaking English. It means that, when the students more practice speak English, they can communicate actively and fluently. Many students cannot use English fluently either inside or outside the classroom. Because English is not their mother tongue and there is no enough time to practice. It is rarely used and they tend to use their mother tongue in daily activities to interact with others. In addition, many of them become worried, nervous and afraid of making mistakes when they use their English. This kind of situation is called anxiety.

Anxiety is a feeling where someone hesitant with their ability or what they want to do. It can be described that someone having low confidence so that they can't get maximal of their life. Related to the definition of anxiety, there are some different opinions of experts about anxiety. Anxiety is feelings of self-consciousness, desire to speak perfectly, and fear of making mistakes (Horwitz, 1981). Meanwhile, Spielberger (Zahiri, Sibarani, and Sumarsih, 2017) stated that anxiety is the subjective feeling of tension, apprehension, nervousness, and worry associated with an arousal of the autonomic nervous system. It means that anxiety is a factor of hindrance in speaking that should be avoided or decreased by the students.

There are two levels of anxiety. The first level is low anxiety. When the student has low anxiety; automatically he or she has low ability in speaking. The optimal anxiety is the second level. When the student has optimal anxiety; automatically he or she has a high ability in speaking (Deyuan He,2018). The level of anxiety is very crucial. It is not easy to identify. In conclusion, it occurs when the students feel anxious, nervous, and afraid to express their feelings.

On preliminary research on January 2019/2020 at SMAN 1 Pantai Cermin Kabupaten Solok, the researcher conducted observation and interviewed one of the English teachersRisfanelti and some students to find some problems related to the students' anxiety and speaking performance. In addition, some students had anxieties when speaking in front of the class while some other students had no problems. The researcher found some of the problems. First, some of the students felt afraid to get negative opinion when they spoke beside their friend. Based on observation, fear of negative opinions appeared when the teacher asks some students to speak English in material cause and effect. When some students will start to talk, then other friends refute and some laugh and the students who are 
asked to speak feel scared and silent. Thus, some students who felt anxious about their negative opinion become afraid to express their ideas in English in front of many people.

Secondly, some students have a lack of confidence and lack of vocabulary when they spoke besides their friend is a second problem (Wiraldi, Jufriadi, 2020). Based on the interview, they admitted that speaking performance was a serious problem in learning English. Some students said that they did not have vocabulary mastery and less knowledge of grammar in English. Hence, they were being able to speak English fluently. Then, some students appeared to be shy, not comfortable, and not confident in practising speaking English. However, in other condition, some students cannot appear to be shy. Thus, it can be concluded that vocabulary mastery, grammar knowledge, influent, students' self-problem affected their achievement in speaking performance (Iksan \& T. Palangngan, 2018).

Based on the explanation above, the researcher was interested in research "The Correlation between Students'Anxiety and Speaking Performance at Second Grade in SMAN 1Pantai Cermin Kabupaten Solok".

\section{METHODS.}

This section looks into the study design, population and sample size, research instrument, data collection instruments, and analysis methods.

\section{Study Design}

This research used the quantitative approach in the form of a correlational one because the researcher used a numerical system to find the data.

\section{Population}

The population of this research was all class of second grade in SMAN 1 Pantai Cermin Kabupaten Solok in the 2020/2021 academic years, which consists of four classes. The population would be described in the table below:

Table 1. The Total of Second Students

\begin{tabular}{ccc}
\hline No. & Class & Total Students \\
\hline 1. & XI IPA 1 & 25 Students \\
2. & XI IPA 2 & 23 Students \\
3. & XI IPS 1 & 25 Students \\
4. & XI IPS 2 & 24 Students \\
Total & & 97 Students \\
\hline
\end{tabular}

Source: Administration Staffs of SMAN 1 Pantai Cermin Kabupaten Solok 


\section{Sample Size}

From the data in population, it showed that the data of the population was more than 100 students. Arikunto stated that if the population is less than a hundred, it must be taken all as the sample. However, if the population was a hundred or more, it should be taken $10 \%$ $15 \%$ or $20 \%-25 \%$ or even more. Indeed, the sample of this research was 97 students from all class because the population was less than a hundred.

\section{Instruments}

The researcher got the data from two kinds of instrumentation that were questionnaire and documentation.

\section{Questionnaire}

To get the data, the researcher used a closed questionnaire. The questionnaires were adapted from (Horwitz,1986) about the Foreign Language classroom anxiety scale (FLCAS) then the researcher adapted the questionnaires to be translated into Indonesian, to make it easy and avoid misunderstanding of the respondents on the content of the questionnaire. The FLCAS questionnaires were distributed to all students in the second grade in SMAN 1 Pantai Cermin. Then, the students were asked to fill or give a checklist of the statements. The students responded to the items on the questionnaire in 15 minutes.

Practically, FLCAS consists of three components such as communication apprehension, test anxiety, and fear negative evaluation. The FLCAS consists of 33 statements. The questionnaire was divided into positive statements and negative statements. The questionnaire was used a Likert Scale model which very disagreed, disagree, neither agree and disagree, agree and very agreeable. In this research, the researcher gave a score of 5 for those who chose very Agree. If the students chose to agree, they gave a score of 4 . While score 3 for those students who chose less agree. Score 2 gave for the students who chose disagree, and score 1 gave for the students who chose very disagree. It can be seen on the table below:

Table2. Scala of Likert Scale

\begin{tabular}{lcc}
\hline \multicolumn{1}{c}{ Alternative Opinions } & Positive & Negative \\
\hline Very Agree & 5 & 1 \\
Agree & 4 & 2 \\
Less Agree & 3 & 3 \\
Disagree & 2 & 4 \\
Very Disagree & 1 & 5 \\
\hline
\end{tabular}

Source: Suharsimi Arikunto's book

The data calculated manually with a range of score from 33 to 165 . The last score took from the total answers to a questionnaire given by the researcher. In addition, the high and low score showed the anxiety range. If the students obtained a score of 33 to 98 , they had 
low anxiety. Whereas, if the students achieved a score of 99 to 165 , they had high anxiety. In conclusion, by using a Likert scale, the researcher was easier to measure the students' score on the statements in the questionnaire.

From the questionnaire, the researcher got the level of students' anxiety after being calculated the score from each number. Besides, the Likert scale was more flexible than other measurement techniques. The number of items or statements was up to the consideration of researchers.

\section{Documentation}

The researcher used documentation to collect the data about the students' speaking. The students' score was gotten by the researcher from English teacher of SMAN 1 Pantai Cermin. Where the students' score was known as documentation. The documentation was taken from the students' daily score of speaking because the students often practised speaking on the learning process.

\section{Data collection}

The data was collected as following the steps below:

\section{Questionnaire}

a. Gather the respondents

b. Explain what to do to the respondents

c. Ask the respondents to fill the questionnaire

d. Distribute the questionnaire to the respondents

e. Collect the answer sheet

\section{Documentation}

a. The researcher got the score of speaking performance from the teacher.

b. The researcher collects the students' score from each class

\section{Data Analysis Technique}

The researcher analyzed the data using Pearson Product Moment (Geoffrey E. Mills, 2018) by the assistant of SPSS 20 for windows.

\section{RESULTS}

Students Anxiety And Speaking Performance

Table 3. Students' Anxiety Score (XI MIA 1)

\begin{tabular}{ccc}
\hline No & Students & EI score \\
\hline 1 & AH & 97 \\
2 & ASM & 86 \\
3 & A & 113 \\
4 & AJ & 92 \\
\hline
\end{tabular}




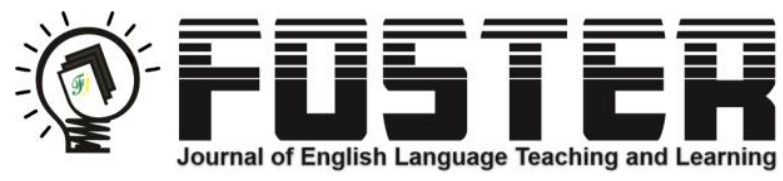

Copyright (C) The Author(s)

Vol. 2, No. 2, April 2021

$e$-ISSN: 2723-4126

\begin{tabular}{ccc}
\hline 5 & DS & 96 \\
6 & DWA & 106 \\
7 & FAZ & 96 \\
8 & FO & 75 \\
9 & FJ & 99 \\
10 & HEP & 93 \\
11 & HAP & 121 \\
12 & II & 97 \\
13 & IJ & 96 \\
14 & JT & 94 \\
15 & LS & 122 \\
16 & MM & 93 \\
17 & NS & 101 \\
18 & NA & 119 \\
19 & OS & 102 \\
20 & RYP & 75 \\
21 & RS & 87 \\
22 & TMP & 84 \\
23 & YAS & 112 \\
24 & YQA & 102 \\
25 & Zs & 109 \\
\hline
\end{tabular}

Table 4. Students' Anxiety Score (XIMIA 2)

\begin{tabular}{ccc}
\hline NO & NAMA & EI Score \\
\hline 1 & AJ & 80 \\
2 & AZ & 92 \\
3 & AF & 115 \\
4 & BA & 100 \\
5 & CRB & 93 \\
6 & DM & 113 \\
7 & FR & 94 \\
8 & FS & 104 \\
9 & GAR & 116 \\
10 & HA & 85 \\
11 & HAP & 116 \\
12 & IM & 126 \\
13 & JK & 111 \\
14 & LF & 125 \\
15 & MBDR & 118 \\
16 & MA & 105 \\
17 & N & 107 \\
18 & PK & 115 \\
19 & PM & 131 \\
20 & RA & 113 \\
21 & SW & 102 \\
22 & VS & 98
\end{tabular}




\begin{tabular}{ccc}
23 & ZRW & 112 \\
\hline & Table 5. Students' Anxiety Score (XIIPS 1) & \\
NO & NAMA & EI Score \\
\hline 1 & AEP & 104 \\
2 & AP & 96 \\
3 & AR & 92 \\
4 & ANY & 98 \\
5 & AH & 96 \\
6 & AAP & 94 \\
7 & DPS & 92 \\
8 & FS & 96 \\
9 & FF & 94 \\
10 & FS & 92 \\
11 & HP & 94 \\
12 & MR & 88 \\
13 & MR & 97 \\
14 & NR & 93 \\
15 & PCA & 94 \\
16 & PR & 98 \\
17 & RAY & 90 \\
18 & RPO & 88 \\
19 & RH & 92 \\
20 & RS & 94 \\
21 & SS & 94 \\
22 & SAP & 92 \\
23 & SO & 94 \\
25 & SR & 98 \\
& TI & 94 \\
\hline
\end{tabular}

Table 6. Students' Anxiety Score (XIIPS 2)

\begin{tabular}{ccc}
\hline NO & NAMA & EI Score \\
1 & AI & 94 \\
2 & AP & 92 \\
3 & AR & 94 \\
4 & AA & 94 \\
5 & AR & 94 \\
6 & AK & 80 \\
7 & DH & 92 \\
8 & DY & 94 \\
9 & DCH & 95 \\
10 & EM & 97 \\
11 & FRA & 88 \\
12 & FZ & 94 \\
13 & FR & 92 \\
\hline
\end{tabular}




\begin{tabular}{lcc}
\hline 14 & HN & 90 \\
15 & IMA & 92 \\
16 & KP & 94 \\
17 & MN & 93 \\
18 & MI & 92 \\
19 & MF & 98 \\
20 & RA & 94 \\
21 & RD & 88 \\
22 & SW & 92 \\
23 & SA & 93 \\
24 & SS & 92 \\
\hline
\end{tabular}

Table 7. Students'Speaking Score XIMIA 1

\begin{tabular}{ccc}
\hline NO & NAMA & EI Score \\
\hline 1 & AH & 65 \\
2 & ASM & 75 \\
3 & A & 70 \\
4 & AJ & 70 \\
5 & DS & 65 \\
6 & DWA & 65 \\
7 & FAZ & 65 \\
8 & FO & 70 \\
9 & FJ & 60 \\
10 & HEP & 70 \\
11 & HAP & 85 \\
12 & II & 65 \\
13 & IJ & 65 \\
14 & JT & 65 \\
15 & LS & 65 \\
16 & MM & 65 \\
17 & NS & 60 \\
18 & NA & 70 \\
19 & OS & 80 \\
20 & RYP & 65 \\
21 & RS & 80 \\
22 & TMP & 80 \\
23 & YAS & 75 \\
24 & YQA & 70 \\
25 & Zs & 70 \\
\hline
\end{tabular}


Table 8. Students'Speaking Score XIMIA 2

\begin{tabular}{|c|c|c|}
\hline NO & NAMA & EI Score \\
\hline 1 & $\mathrm{AJ}$ & 65 \\
\hline 2 & $\mathrm{AZ}$ & 75 \\
\hline 3 & $\mathrm{AF}$ & 80 \\
\hline 4 & $\mathrm{BA}$ & 65 \\
\hline 5 & CRB & 70 \\
\hline 6 & $\mathrm{DM}$ & 85 \\
\hline 7 & FR & 70 \\
\hline 8 & FS & 80 \\
\hline 9 & GAR & 75 \\
\hline 10 & HA & 75 \\
\hline 11 & HAP & 85 \\
\hline 12 & IM & 80 \\
\hline 13 & $\mathrm{JK}$ & 60 \\
\hline 14 & LF & 75 \\
\hline 15 & MBDR & 60 \\
\hline 16 & MA & 75 \\
\hline 17 & $\mathrm{~N}$ & 70 \\
\hline 18 & $\mathrm{PK}$ & 75 \\
\hline 19 & $\mathrm{PM}$ & 60 \\
\hline 20 & $\mathrm{RA}$ & 85 \\
\hline 21 & SW & 80 \\
\hline 22 & VS & 85 \\
\hline 23 & ZRW & 85 \\
\hline \multicolumn{3}{|c|}{ Table 9.Students'Speaking Score XIIPS 1} \\
\hline NO & NAMA & EI Score \\
\hline 1 & $\mathrm{AEP}$ & 60 \\
\hline 2 & $\mathrm{AP}$ & 75 \\
\hline 3 & $\mathrm{AR}$ & 65 \\
\hline 4 & ANY & 60 \\
\hline 5 & $\mathrm{AH}$ & 80 \\
\hline 6 & AAP & 65 \\
\hline 7 & DPS & 75 \\
\hline 8 & FS & 80 \\
\hline 9 & $\mathrm{FF}$ & 65 \\
\hline 10 & FS & 75 \\
\hline 11 & HP & 65 \\
\hline 12 & MR & 60 \\
\hline 13 & MR & 85 \\
\hline 14 & NR & 60 \\
\hline 15 & PCA & 85 \\
\hline
\end{tabular}




\begin{tabular}{lcc}
16 & PR & 65 \\
17 & RAY & 65 \\
18 & RPO & 85 \\
19 & RH & 80 \\
20 & RS & 65 \\
21 & SS & 60 \\
22 & SAP & 65 \\
23 & SO & 85 \\
24 & SR & 75 \\
25 & TI & 80 \\
\hline
\end{tabular}

Table 10. Students' Speaking Score XIIPS 2

\begin{tabular}{ccc}
\hline NO & NAMA & EI Score \\
\hline 1 & AI & 85 \\
2 & AP & 80 \\
3 & AR & 70 \\
4 & AA & 65 \\
5 & AR & 70 \\
6 & AK & 60 \\
7 & DH & 80 \\
8 & DY & 70 \\
9 & DCH & 65 \\
10 & EM & 65 \\
11 & FRA & 70 \\
12 & FZ & 65 \\
13 & FR & 60 \\
14 & HN & 60 \\
15 & IMA & 80 \\
16 & KP & 65 \\
17 & MN & 75 \\
18 & MI & 65 \\
19 & MF & 65 \\
20 & RA & 70 \\
21 & RD & 70 \\
22 & SW & 75 \\
23 & SA & 60 \\
24 & SS & 80 \\
\hline
\end{tabular}


Table 11. Correlations

\begin{tabular}{llrr}
\hline & \multicolumn{3}{c}{ Correlations } \\
\hline & & students anxiety & \multicolumn{2}{c}{ speaking } \\
performance
\end{tabular}

The table above showed the correlation coefficient equalled $r=0.143$, which indicated there was a positive correlation between the two variables. From the $r$ number $(0.143)$ the researcher could use it to know the strength of correlation between two variables. The number of 0.143 resided between $0.000-0.200$ which means the strength is very low correlation.

Based on the table above can answer the third question in this research :

a. Is there any significant correlation between students' emotional intelligence and speaking achievement?

The correlation coefficient which shows the relationship between students anxiety and speaking performance is 0,143 . Thus, there is a significant correlation between students anxiety and speaking performance.

b. What is the correlation direction between students' anxiety and speaking performance?

To answer the second question of this research, the correlation coefficient that shows the correlation between anxiety and speaking performance is 0,143 . Namely, there is a significant correlation between student anxiety and speaking performance because the result of this calculation has a positive symbol.

c. What is the magnitude of the relationship between students' anxiety and speaking performance?

To know the magnitude of the correlation between students anxiety and speaking performance, the researcher consults with the interpretation table below: 
Table 12: Magnitude of Correlation

\begin{tabular}{cc}
\hline Coefficient & Magnitude of correlation \\
$0,80-1,00$ & Very High \\
$0,60-0,79$ & High \\
$0,40-0,59$ & Sufficient \\
$0,20-0,39$ & Low \\
$0-0,19$ & Very Low \\
\hline
\end{tabular}

Source: Lijan Poltak Sinambela, Metodologi Penelitian Kuantitatif, ..., p. 208

Shortly, the correlation coefficient that shows the correlation between students anxiety and speaking performance is 0,143 . This interpretation answers the third question in this research. Based on the interpretation table above, 0,143 has a "very low" correlation because it is between $0,00-0,19$. It can be concluded that the magnitude of the correlation between student anxiety and speaking performance is very low.

\section{DISCUSSION}

Based on the data analysis above, the researcher has found that the coefficient of correlation between students anxiety and speaking performance at the second grade of SMAN 1 Pantai Cermin Kabupaten Solok was 0,143. There is a positive correlation between the two variables because the result has a positive symbol. From the result above, the magnitude of the correlation is very low because it is between $0-0,19$. If the students have high anxiety automatically she/he have the low ability in speaking or when the students have low anxiety automatically she/he have high ability in speaking performance.

This research is about the correlation between students' anxiety and speaking performance at the second grade of SMAN 1 Pantai Cermin Kabupaten Solok. It can be said that correlates between students' anxiety as variable $\mathrm{X}$ and speaking performance as variable $Y$. The data are gotten from questionnaire and documentation. The questionnaire uses a Likert scale which consists of "strongly disagree, disagree, neither agree, agree, and strongly agree" for responding.

In analysis data, the researcher calculated students' anxiety and speaking score by using the Product Moment Formula. It is found that there is a correlation between students' anxiety and speaking performance at the second grade of SMAN 1 Pantai Cermin Kabupaten Solok. Moreover, there is also a positive correlation between the two variables. A positive correlation has meant that if the students have high anxiety automatically she/he have the low ability in speaking or when the students have low anxiety automatically she/he have high ability in speaking performance. This research supporting by the theory from Walker in Deyuan He. According to Walker in Deyuan He, there are two levels of anxiety. The first level is low anxiety. When the student has low anxiety; automatically he or she has low ability in 
speaking. The optimal anxiety is the second level. When the student has optimal anxiety; automatically he or she has a high ability in speaking.

Additionally, based on hypothesis testing, the result of $r_{x y}$ is 0,143 , and r-table is 0,1996 on $\mathrm{df}=97-2=95$, alpha $=0,05$. Because $r_{x y}$ is smaller than the r-table, Ha is rejected and Ho is accepted. It means that there is a correlation between students' anxiety and speaking performance at the second grade of SMAN 1 Pantai Cermin Kabupaten Solok. In summary, the result of this research supports the research hypothesis that there is a very low correlation between students' anxiety and speaking performance at the second grade of SMAN 1 Pantai Cermin Kabupaten Solok.

\section{CONCLUSION}

The purpose of this research is to know whether there is a correlation or not between students' anxiety and speaking performance at the second grade of SMAN 1 Pantai Cermin Kabupaten Solok. In this research, students' anxiety score and the students' speaking performance have a correlation. The result of the research indicated that the students' anxiety and speaking performance have a positive correlation. Students anxiety influenced their speaking performance, it was shown by the result of their test. Briefly, if the students have high anxiety automatically she/he have the low ability in speaking performance or when the students have low anxiety automatically she/he have high ability in speaking performance.

\section{ACKNOWLEDGMENT}

As a result, the writer wants to highly express her sincere gratitude and appreciation to the following person for their valuable contributions.

1. Syahrul, M. Pd as an advisor for her care, time, attention, guidance, valuable advice, suggestion, critics and patience in accomplishing this thesis. Her suggestions and contributions are highly appreciated.

2. All of the lecturers who have given their knowledge, ideas, and contributions to the completion of this journal and educated his precious things in many fields during his study.

3. The writer also shows thanks to my beloved family, especially for my dad and mom (Kasri and Samsimar), all of my sisters (Dodi Putra, Tipa Yunita and Peri Oktaviadi, Savira Amanda) who had given their love, pray and supports to accomplish this thesis soon.

4. The writer also shows thanks to beloved friend Refa Yando, Yona Meidiastitu and another friend. Thanks for the support, motivate, and suggest to finish this study.

\section{REFERENCES}

Pamungkas, Adji. (2018). The effect of English language Anxiety on Speaking Performance. (Surabaya State Univerrsity.Vol 6 No. 3 T) 
Arikunto S. (1998). Procedure Penelitian: (Rineka Cipta: Jakarta)

Budi Susetyo. (2010). Statistika Untuk Analisis Data Penelitian, (Bandung: PT. Refika Aditama)

Deyuan He. (2018). Foreign Language LearningAnxiety in China-Theories and Applications in EnglishLanguage Teaching. (Kowloon, Hong Kong)

Geoffrey E. Mills, L. R. G. (2018). Educational Research: Competencies for Analysis and Applications. In Educational Research (12th ed.). Pearson Education, Inc.

Iksan, M., \& Duriani. (2015). A Survey of Students' Language Learning Strategies and Their English Learning Achievement in SMA Negeri 1 Palopo. IDEAS: Journal on English Language Teaching and Learning, Linguistics and Literature, 3(2), 12-27. https://doi.org/10.24256/ideas.v3i2.146

Iksan, M., \& T. Palangngan, S. (2018). Pemberdayaan remaja masjid sebagai fasilitator pembelajaran bahasa inggris di desa lestari kecamatan tomoni kabupaten luwu timur. Prosiding Seminar Nasional, 03, 16-23.

H. Douglas Brown. (1994). Teaching by Principles: An Interactive Approach to Language Pedagogy. (New Jersey: Prentice-Hall.)

H. Douglas Brown. (2003). Language Assessment, Principle and Classroom Practice (Longman)

Horwitz, Horwitz and Cope. (1991). English Language Learning Strategy, (Handbook)

Jack C. Richards. (2008). Teaching speaking and Listening from Theory to Practice, (NewYork, Cambridge,).

Leila Mohtasham and Maryam Farnia (2017) "English Speaking Anxiety: A study of the Effect of Gender on Iranian EFL University Students Perception". International Journal of Research In English Education. Vol.2 No.4.

Louise Cohen, et al. (2007). Research methods in Education, (London: Taylor\&Francis Group).

Lucas, R. I., Miraflores, E\& Go, D. (2011). English Language Learning Anxiety among Foreign Language Learners in the Philippines. Philippine ESL Journal, 7, 102113. Retrieved from http://www.philippine-esljournal.com/V7-A5.pdf.

Mayer, D. P. (2008). Overcoming School Anxiety: How to Help Your Child Deal with Separation, Tests, Homework, Bullies, Math Phobia, and Other Worries. (United States of America. Library of Congress Cataloging-in-Publication Data.)

Nunan, D. 2003. Practical English Language Teaching. (New Yok: McGraw-Hill)

Penny Ur. 1991. A course of language Teaching, Practice and Theory, (Cambridge University Press, New York)

Soradova, Daniela, 2015. Foreign language learning anxiety. (Handbook) 
Sugiyono, 2017.MetodePenelitiankuantitatif, kualitatifdan R\&D, Bandung: Alfabeta)

Wiraldi, Jufriadi, M. I. (2020). Improving Vocabulary Mastery of The Seventh Year Students Using Scattergories Game in SMP Negeri 8 Palopo. FOSTER: Journal of English Language Teaching, 1(2), 159-167.

Zahiri, Sibarani, and Sumarsih. 2017. To What Extent Do Anxiety and Self Efficacy Effect the EFL Students English Monologue Speaking Skill. (International Journal of Education and Research) 